Article

\title{
Development of a Novel Methodology to Assess the Corrosion Threshold in Concrete Based on Simultaneous Monitoring of $\mathrm{pH}$ and Free Chloride Concentration
}

\author{
Yurena Seguí Femenias ${ }^{1}$, Ueli Angst ${ }^{1, * \mathbb{C}}$, Fabrizio Moro ${ }^{2}$ and Bernhard Elsener ${ }^{1,3}$ \\ 1 Institute for Building Materials (IfB), ETH Zürich, Stefano-Franscini-Platz 3, 8093 Zurich, Switzerland; \\ syurena@ethz.ch \\ 2 Lafargeholcim Research Center, 95, rue du Montmurier, BP 15, 38291 Saint-Quentin Fallavier, France; \\ fabrizio.moro@lafargeholcim.com \\ 3 Department of Chemical and Geological Sciences, University of Cagliari, 09100 Monserrato (CA), Italy; \\ elsener@ifb.baug.ethz.ch \\ * Correspondence: ueli.angst@ifb.baug.ethz.ch; Tel.: +41-44-633-4024
}

Received: 7 August 2018; Accepted: 11 September 2018; Published: 14 September 2018

\begin{abstract}
Both the free chloride concentration and the $\mathrm{pH}$ of the concrete pore solution are highly relevant parameters that control corrosion of the reinforcing steel. In this paper, we present a method to continuously monitor these two parameters in-situ. The approach is based on a recently developed electrode system that consists of several different potentiometric sensors as well as a data interpretation procedure. Instrumented mortar specimens containing different amounts of admixed chlorides were exposed to accelerated carbonation, and changes in free chloride concentration and $\mathrm{pH}$ were monitored simultaneously over time. The results revealed the stepwise decrease in $\mathrm{pH}$ as well as corresponding increases in free chlorides, resulting from the release of bound chlorides. For a $\mathrm{pH}$ drop of about 1 unit (from $\mathrm{pH} 13.5$ down to $\mathrm{pH} 12.5$ ), the free chloride concentration increased up to 1.5 -fold. We continuously quantified the ratio $\mathrm{Cl}^{-} / \mathrm{OH}^{-}$that increased steeply with time, and was found to exceed a critical corrosion threshold long before carbonation can be detected with traditional indicator spray testing, even at admixed chloride contents in the order of allowable limits. These results can strongly influence the decision-making in engineering practice and it is expected to significantly improve condition assessments of reinforced concrete structures.
\end{abstract}

Keywords: chloride sensor; pH sensor; reinforced concrete; durability; corrosion; carbonation; monitoring; structural health monitoring

\section{Introduction}

Reinforced Concrete (RC) is the world's most used building material [1], it is widely used in infrastructures, e.g., tunnels, garages, bridges, and in many public and private buildings. However, the service life of RC structures may be limited due to some deterioration mechanisms, amongst them, corrosion of the steel reinforcement is the most widespread in many parts of the world [2,3].

In the concrete alkaline environment, steel is in the passive state, i.e., with a negligible corrosion rate $[4,5]$, but this passivity can be lost due to the presence of chlorides or to a decrease in the pore solution $\mathrm{pH}$ (for example, due to $\mathrm{CO}_{2}$ ingress) at the reinforcement level $[4,5]$. Once passivity is lost, corrosion initiates, leading to the loss of rebar cross section and hence, to the decrease in structural safety.

Corrosion does not only concern the structural safety, but it also has a major effect on the economy of all industrialized countries [6-9]. For example, in 2013 the global cost of corrosion was reported 
to be about 3.4\% of the U.S. Gross Domestic Product (GDP) [9]. This situation will aggravate in the next years, as the number of structures reaching a critical age will markedly increase [6-8]. This is because a large part of the reinforced concrete infrastructure was built in the second half of the last century; thus, a considerable number of RC structures will have to operate beyond their design life in the next years. The risk of corrosion in these structures is relatively high, as they have been long exposed to ingress of chlorides and $\mathrm{CO}_{2}$ (the main aggressive agents that lead to corrosion initiation). Currently, there is a lack of knowledge to determine whether a structure can still be in service at this point; this forces engineers to take conservative decisions, leading to the early repair of the structure [8]. Consequently, the increasing number of structures reaching a critical age will lead to an increased number of structures to be repaired and thus, to a significant increase of corrosion costs. Therefore, it is essential to quit the current conservative and costly approaches and find cost-effective solutions. Structural health monitoring offers large opportunities to significantly reduce these costs.

\section{Structural Health Monitoring for Assessing Corrosion in Reinforced Concrete Structures}

In this study, structural health monitoring is based on the continuous measurement of the relevant parameters related to corrosion risk and propagation. This information provides advance warning for corrosion and it allows taking remedial actions well before damage appears. Corrosion onset can be then delayed and structures can be used safely for longer times, thus reducing the costs associated with corrosion $[7,8,10]$.

Monitoring systems based on embedded sensors [11] are the basis for this early detection of corrosion. In the last years, such embeddable sensors have been developed and installed in concrete structures. A notable corrosion monitoring system is the so-called anode-ladder system [12,13], which is composed of steel rods, placed at different depths from the concrete surface. The penetration of the corrosion front is based on the measurement of a macrocell current between steel reinforcement and steel rods comprising the anode-ladder. Other sensor systems based on the macrocell measurements can be found in References $[14,15]$. Another attractive solution to monitor corrosion onset was proposed by Leung et al. [16]. The authors developed a fiber optic sensor where the flat end of a cut optical fiber is coated with an iron thin film (in the order of hundred nanometers). As corrosion occurs, the film thickness decreases with time and consequently, the reflected signal drops. Monitoring the reflected signal is used as a way to assess if the concrete environment at the sensor location may induce steel corrosion or not. Other approaches to monitor corrosion are based on in-depth resistivity measurements, e.g., multi-ring electrode [17].

All the sensors described above give information regarding the corrosion state of the reinforcement once corrosion has initiated. Sensors to monitor chloride concentration and $\mathrm{pH}$ of the concrete pore solution, on the other hand, would provide information well before corrosion initiates, since the ingress of aggressive substances can be continuously monitored and the risk of corrosion initiation determined at each time. In this regard, $\mathrm{Ag} / \mathrm{AgCl}$ ISEs have successfully been used in mortar and concrete specimens to monitor the free chloride concentration in the pore solution [18-20]. However, the other at least as important information, namely the pore solution $\mathrm{pH}$ is so far not accessible. Only three studies [21-23] reported the non-destructive monitoring of $\mathrm{pH}$ in concrete, based on the use of embedded iridium oxide electrodes. Nevertheless, in both cases the measured pore solution $\mathrm{pH}$ was not coupled with information regarding the free chloride concentration in the pore solution. Additionally, the use of potentiometric sensors in concrete is limited due to the lack of a long-term stable embeddable reference electrodes [24] and the presence of diffusion potentials [25], arising from gradients in chloride concentration and/or $\mathrm{pH}$, which are a known to be a major source of error when using this type of sensors in concrete [26].

A novel sensor system, based on a combination of several $\mathrm{Ag} / \mathrm{AgCl}$ ion-selective electrodes and several iridium/iridium oxide $\left(\mathrm{IrO}_{\mathrm{x}}\right)$ electrodes embedded in mortar, in combination with an algorithm, was developed in a previous work [27]. This novel sensor system allows obtaining, for the first time, $\mathrm{pH}$ and chloride profiles in-situ and non-destructively in concrete. In this paper, we present 
the application of this novel method, by monitoring $\mathrm{pH}$ and free chloride concentration in mortar samples containing admixed chlorides and exposed to accelerated carbonation. The implications of the results obtained are hereby discussed.

\section{Theoretical Background}

\subsection{The Silver/Silver Chloride Ion-Selective Electrode ( $\mathrm{Ag} / \mathrm{AgCl} \mathrm{ISE}$ )}

In this work, a silver/silver chloride ion-selective electrode ( $\mathrm{Ag} / \mathrm{AgCl}$ ISE) is used as a chloride sensor $[18,28,29]$. This is a solid-state membrane electrode [30] that consists of a silver wire with a coating of silver chloride. In the presence of chlorides, the potential response $E_{\mathrm{Ag} / \mathrm{AgCl}}$ of the $\mathrm{Ag} / \mathrm{AgCl}$ ISE is:

$$
E_{\mathrm{Ag} / \mathrm{AgCl}}=E_{\mathrm{Ag} / \mathrm{AgCl}}^{0}-\frac{R T}{F} \ln a_{\mathrm{Cl}^{-}}
$$

where $R$ is the gas constant $\left(8.314 \mathrm{~J} \cdot \mathrm{mol}^{-1} \cdot \mathrm{K}^{-1}\right), F$ the Faraday constant $\left(96.485 \times 10^{3} \mathrm{C} \cdot \mathrm{mol}^{-1}\right), T$ the absolute temperature $(\mathrm{K}), a_{\mathrm{Cl}^{-}}$the activity of the chloride ion, and $E_{\mathrm{Ag} / \mathrm{AgCl}}^{0}$ is the $\mathrm{Ag} / \mathrm{AgCl}$ electrode standard potential $\left(E_{\mathrm{Ag} / \mathrm{AgCl}}^{0}=225.6 \mathrm{mV}\right.$ vs. $\mathrm{Ag} / \mathrm{AgCl} / \mathrm{sat}$. $\mathrm{KCl}$ at $20^{\circ} \mathrm{C}$ [31] $)$.

Previous works showed that these electrodes exhibit a well-defined potential response for a given concentration of chlorides with an accuracy of $\approx \pm 0.05 \mathrm{~mol} \cdot \mathrm{L}^{-1}[28,29]$. It was also found that at low concentration (or in absence) of chlorides, the potential response of this electrode is not well-defined, i.e., it is not stable over time; however, as soon as these sensors come in contact with chlorides, they exhibit expected potential responses according to Equation (1). Therefore, even if these sensors do not provide a stable potential response in absence of chlorides, they will work reliably as chloride sensors as soon as chlorides are present $[18,28,29]$. A factor that can impair the functionality of these electrodes is the presence of sulfide ions, e.g., slag cement [28,29].

More detailed information on the use of this electrode as chloride sensor in concrete can be found in References [18,28,29,32].

\subsection{The Iridium/Iridium Oxide $\left(\operatorname{IrO}_{x}\right)$ Electrode}

This work uses iridium/iridium oxide $\left(\mathrm{IrO}_{\mathrm{x}}\right)$ electrodes as $\mathrm{pH}$ sensors. These electrodes were produced by thermal oxidation of iridium wires, based on the procedure reported in Reference [33]. As recommended in Reference [33], the $\mathrm{IrO}_{x}$ electrodes were first conditioned in alkaline solution ( $\mathrm{pH} 13.5-\mathrm{pH}$ 9) for 2-6 months and then individually calibrated in solution ( $\mathrm{pH} 13.5-\mathrm{pH} 9$ ). The obtained potential response $E_{\mathrm{IrO}}$ of the $\mathrm{IrO}_{\mathrm{x}}$ electrodes is:

$$
E_{\mathrm{IrO}_{\mathrm{x}}}=E_{\mathrm{IrO}_{\mathrm{x}}}^{0}-b \cdot p H
$$

where $E_{\mathrm{IrO}_{x}}^{0}$ is the electrode standard potential and $b$ the potential-pH $\left(E_{\mathrm{IrO}_{\mathbf{x}}}-p H\right)$ slope. Note that $E_{\mathrm{IrO}}^{0}$ and $b$ were obtained from the individual calibration of each produced $\mathrm{IrO}_{\mathrm{x}}$ electrode.

In Reference [33], it was shown that when properly conditioned and individually calibrated, the electrodes respond to $\mathrm{pH}$ according to Equation (2) with a maximum error of $0.5 \mathrm{pH}$ units over a range of at least $\mathrm{pH}$ 9-13.5. More detailed information on the use of this electrode as $\mathrm{pH}$ sensors in concrete can be found in References [33,34].

\section{Experimental Protocol}

\subsection{Electrodes Set-Up}

In order to ensure accurate positioning of the electrodes at the desired cover depth, each $\mathrm{IrO}_{\mathrm{x}}$ electrode and each $\mathrm{Ag} / \mathrm{AgCl}$ ISE was mounted inside a rigid stainless steel tube (ca. $5 \mathrm{~cm}$ long, $2 \mathrm{~mm}$ diameter), leaving $\approx 5 \mathrm{~mm}$ length of the electrode ( $\mathrm{IrO}_{\mathrm{x}}$ electrode or $\mathrm{Ag} / \mathrm{AgCl}$ ISE) sticking out from the steel tube (Figure 1). The stainless steel tube and the electrode were electrically isolated with a Teflon tube (ca. $6 \mathrm{~cm}$ long, $1 \mathrm{~mm}$ diameter) that was slightly longer than the steel tube. Front and 
back ends were then sealed with an epoxy resin. The diameter of both electrodes $\left(\mathrm{IrO}_{\mathrm{x}}\right.$ electrode and $\mathrm{Ag} / \mathrm{AgCl}$ ISE) is approximately $0.5 \mathrm{~mm}$.

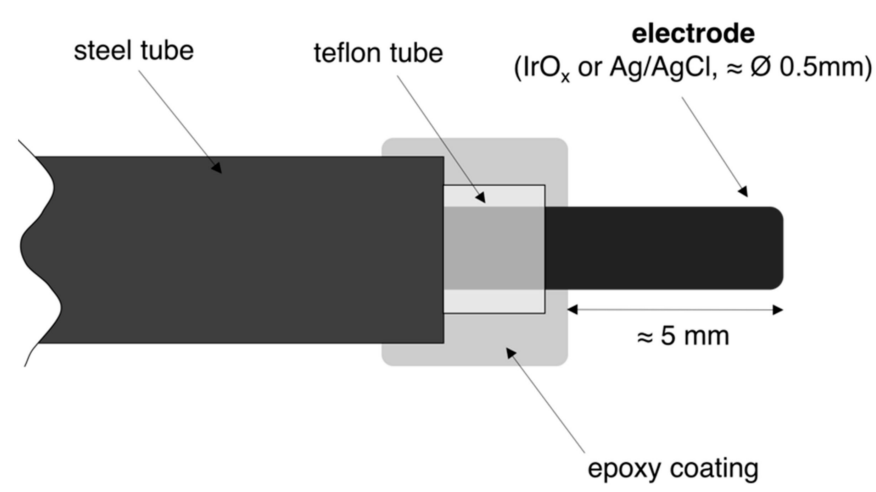

Figure 1. Schematic representation of the set-up used to embed the electrodes (both $\mathrm{IrO}_{\mathrm{x}}$ electrode and $\mathrm{Ag} / \mathrm{AgCl} \mathrm{ISE})$ in mortar.

\subsection{Mortar Samples Preparation}

The mortar samples (Figure 2) consisted of two parts. Mortar prisms $\left(4 \times 4 \times 2.5 \mathrm{~cm}^{3}\right)$ with two embedded $\mathrm{Ag} / \mathrm{AgCl}$ ISEs (at the same cover depth) were first produced with mix proportions cement/water/sand 1:0.5:2, CEM I 52.5, sand size $<1 \mathrm{~mm}$ and containing $4 \%$ of chlorides by cement weight (mix 1 in Figure 2). One hour after casting, another $4.5 \mathrm{~cm}$ thick mortar layer $\left(4 \times 4 \times 4.5 \mathrm{~cm}^{3}\right)$ was cast on top of the previous samples (mix 2 in Figure 2) with two embedded $\mathrm{Ag} / \mathrm{AgCl}$ ISEs and two embedded $\mathrm{IrO}_{\mathrm{x}}$ electrodes. The amount of admixed chlorides varied for this match-cast part: The first two prisms contained $1 \%$ of chlorides by cement weight while the last two prisms contained $0.5 \%$ of chlorides by cement weight. In total, one $\mathrm{IrO}_{\mathrm{x}}$ electrode and one $\mathrm{Ag} / \mathrm{AgCl}$ ISE were embedded at 5 and $20 \mathrm{~mm}$ cover depths (mix 2), and two $\mathrm{Ag} / \mathrm{AgCl}$ ISEs at $55 \mathrm{~mm}$ cover depth (mix 1). Each specimen was made from a different mortar batch.

The four mortar prisms were cured for three days at $95 \% \mathrm{RH}$ and $21^{\circ} \mathrm{C}$. Subsequently, they were exposed for one week to laboratory conditions (ca. $50 \% \mathrm{RH}$ and $21^{\circ} \mathrm{C}$ ). Afterwards, all the surfaces (except one) were painted with an epoxy-resin and the samples were then placed in a carbonation chamber $\left(65 \% \mathrm{RH}, 21{ }^{\circ} \mathrm{C}\right.$, and $\left.4 \% \mathrm{CO}_{2}\right)$ so one-dimensional carbonation occurred through the non-coated surface (Figure 2).

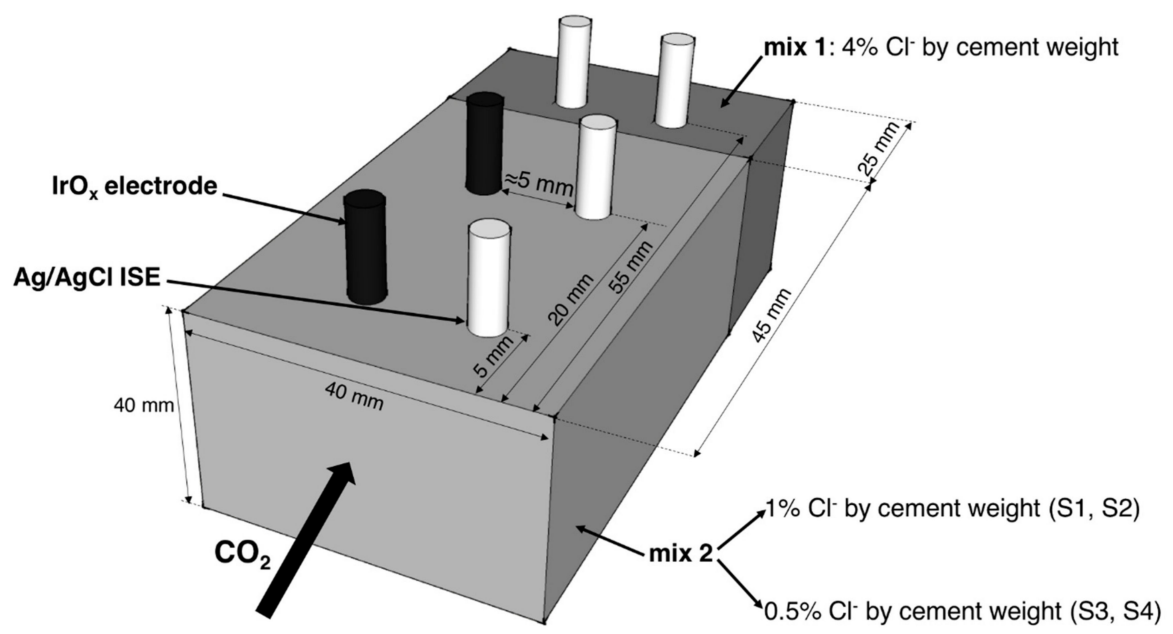

Figure 2. Representation of the mortar samples used to monitor free chloride concentration and $\mathrm{pH}$ (upon carbonation) with $\mathrm{Ag} / \mathrm{AgCl}$ ISEs and $\mathrm{IrO}_{\mathrm{x}}$ electrodes embedded in mixes with different amounts of admixed chlorides (mix 1, mix 2). All the surfaces were coated with epoxy resin with the exception of the surface of $\mathrm{CO}_{2}$ ingress. In total, 4 samples were produced (S1, S2, S3, and S4). 
Table 1 summarizes the amount of chlorides for each sample produced. The chloride content in mix 1 (Figure 2) was always $4 \%$ by cement weight.

Table 1. Amount of chlorides admixed in each mortar sample (compare Figure 2) for each sample produced (S1, S2, S3, S4). All the samples were produced with mix proportions cement/water/sand 1:0.5:2, CEM I 52.5, sand size < $1 \mathrm{~mm}$.

\begin{tabular}{cc}
\hline Sample Name & Amount of Chlorides in Mix 2 (\% by Cement Weight) \\
\hline S1 & $1 \%$ \\
S2 & $1 \%$ \\
S3 & $0.5 \%$ \\
S4 & $0.5 \%$ \\
\hline
\end{tabular}

\subsection{Measurement Procedure}

The potential of all embedded electrodes was continuously measured (with a time interval of $1 \mathrm{~h}$ ) versus one of the $\mathrm{Ag} / \mathrm{AgCl}$ ISE embedded at $50 \mathrm{~mm}$ depth (Figure 2). A Keithley multimeter (Keithley Instruments Inc.) with high input impedance ( $>10 \mathrm{G} \Omega)$, connected to a computer for data acquisition, was used for the potential monitoring. Potential measurements were started immediately after the samples were placed in the carbonation chamber (that is, after three days of curing and one week of drying: Compare with Section 4.2).

It should be noted that the presence of diffusion potentials is likely to be a serious error when performing potentiometric measurements in concrete [26,35-37]. Diffusion potentials in the order of hundreds of $\mathrm{mV}$ have been reported $[37,38]$. It is thus important to correct all measured potentials with respect to the diffusion potential. In this work, all potentiometric measurements were corrected accordingly with a recently developed [27] calculation procedure that integrates Equations (1) and (2). As an output, the algorithm provides the free chloride concentration and the $\mathrm{pH}$ at each electrode location.

\section{Results}

\subsection{Monitoring the Pore Solution $\mathrm{pH}$ during Carbonation Propagation}

Figure 3 shows the measured $\mathrm{pH}$ at $5 \mathrm{~mm}$ (Figure 3a) and $20 \mathrm{~mm}$ depth (Figure $3 \mathrm{~b}$ ) as a function of exposure time in the carbonation chamber. Specimen $\mathrm{S} 4$ is not shown in Figure $3 \mathrm{~b}$ because the $\mathrm{IrO}_{\mathrm{x}}$ electrode embedded at a $20 \mathrm{~mm}$ depth was accidentally broken during the demolding of the sample.

a)

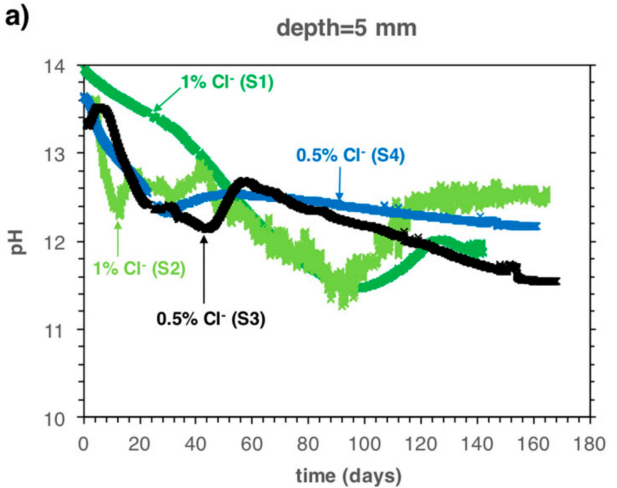

b)

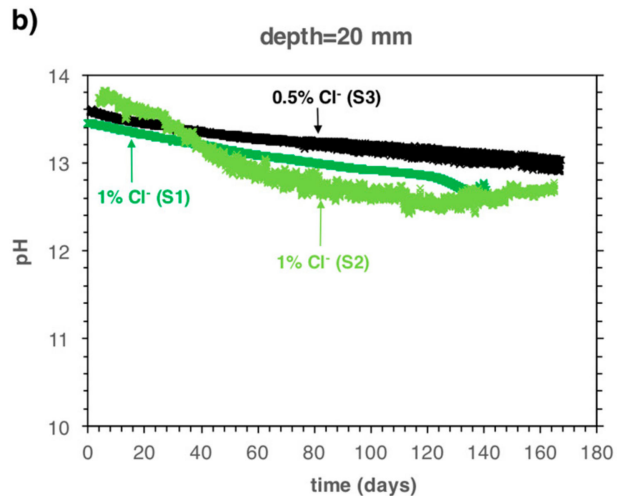

Figure 3. Measured $\mathrm{pH}$ as a function of exposure time in the carbonation chamber at $5 \mathrm{~mm}(\mathbf{a})$ and $20 \mathrm{~mm}$ (b) cover depth. The labels and arrows indicate the amount of admixed chlorides and the name of the specimen.

The electrodes embedded at a $5 \mathrm{~mm}$ depth indicate first a decrease from ca. $\mathrm{pH} 13.5$ down to $\mathrm{pH}$ 12.8-12.2 for samples S3 and S4 (0.5\% admixed chlorides by cement weight). Subsequently, the $\mathrm{pH}$ 
increased back to about $\mathrm{pH} 12.5$ within a few days. Afterwards, the $\mathrm{pH}$ slowly decreased further, reaching $\mathrm{pH} 12-11.5$ after approximately 160 days of $\mathrm{CO}_{2}$ exposure. For samples with $1 \%$ admixed chlorides by cement weight ( $\mathrm{S} 1$ and $\mathrm{S} 2$ ), the $\mathrm{pH}$ decrease was generally delayed, but somewhat more pronounced: it reached a value of $\mathrm{pH} \approx 11.5$ after 100 days in the carbonation chamber, then it increased back to $\mathrm{pH} \approx 12.5$ during the next 20 days and it remained constant at that value after about 140 and 165 days of $\mathrm{CO}_{2}$ exposure for samples S3 and S4, respectively. In a previous work [34], it was indicated that the $\mathrm{pH}$ decrease to $\mathrm{pH}<12.5$, followed by the increase back to 12.5 (where it remains constant for some time) is likely due to the kinetically limited dissolution of Portlandite (which acts as a buffer maintaining the $\mathrm{pH}$ constant at $\approx 12.5$ ), especially under conditions of accelerated carbonation.

At $20 \mathrm{~mm}$ cover depth (Figure $3 \mathrm{~b}$ ) the $\mathrm{pH}$ decreased only slightly and after 140 days of exposure in the carbonation chamber was still clearly higher than $\mathrm{pH} 12.5$ for both the specimens with $0.5 \%$ and $1 \%$ of admixed chloride.

\subsection{Monitoring the Chloride Concentration during Carbonation Propagation}

Table 2 shows the initial free chloride concentrations measured in the samples (initial $=$ at the moment of introducing the samples in the carbonation chamber, i.e., after three days of curing and one week of drying). The initial free chloride concentration in the samples containing $0.5 \%$ of admixed chlorides (S3 and S4) was $0.11 \pm 0.02 \mathrm{~mol} \cdot \mathrm{L}^{-1}$. In the samples with $1 \%$ admixed chlorides (S1 and S2), the initial free chloride concentration was $1.53 \pm 0.1 \mathrm{~mol} \cdot \mathrm{L}^{-1}$. The maximum difference in free chloride concentration between samples with the same amount of admixed chlorides was always $<0.2 \mathrm{~mol} \cdot \mathrm{L}^{-1}$ (Table 2). Note that the $\mathrm{Ag} / \mathrm{AgCl}$ ISE at $5 \mathrm{~mm}$ depth from sample S3 was accidentally broken during demolding; hence, the chloride concentration could not be measured.

Figure 4 shows the measured free chloride concentration at $20 \mathrm{~mm}$ cover depth as a function of exposure time in the carbonation chamber for the different specimens (Table 1). At $20 \mathrm{~mm}$ cover depth, where no significant $\mathrm{pH}$ changes occurred during the exposure time in this study (Figure $3 \mathrm{~b}$ ), the free chloride concentration decreased only slightly $\left(0.1 \mathrm{~mol} \cdot \mathrm{L}^{-1}\right)$ for samples S1 and S2. At such high chloride concentrations $\left(>1.3 \mathrm{~mol} \cdot \mathrm{L}^{-1}\right)$, a difference of $0.1 \mathrm{~mol} \cdot \mathrm{L}^{-1}$ corresponds to a difference of about $10 \mathrm{mV}$ in the potential-chloride activity curve (Equation (1)). Such differences in the calculated electrode potential (Equation (1)) may thus be caused by assumptions made in the calculation procedure [27].

Table 2. Initially measured free chloride concentration at 5 and $20 \mathrm{~mm}$ cover depth, together with the amount of admixed chlorides for the different specimens (S1, S2, S3, S4).

\begin{tabular}{|c|c|c|c|}
\hline \multirow[t]{2}{*}{ Sample Name } & \multicolumn{2}{|c|}{$\begin{array}{l}\text { Initial Measured Free Chloride } \\
\text { Concentration }\left(\mathrm{mol} \cdot \mathrm{L}^{-1}\right)\end{array}$} & \multirow{2}{*}{$\begin{array}{l}\text { Total Chloride Content-Initially Admixed } \\
\text { Chlorides (\% by Cement Weight) }\end{array}$} \\
\hline & $5 \mathrm{~mm}$ depth & $20 \mathrm{~mm}$ depth & \\
\hline S1 & 1.58 & 1.40 & 1.0 \\
\hline $\mathrm{S} 2$ & 1.54 & 1.60 & 1.0 \\
\hline S3 & - & 0.08 & 0.5 \\
\hline $\mathrm{S} 4$ & 0.11 & 0.13 & 0.5 \\
\hline
\end{tabular}

At $5 \mathrm{~mm}$ cover depth, however, where significant $\mathrm{pH}$ changes occurred (Figure $3 \mathrm{a}$ ), this is clearly different. Figure 5 shows both the measured free chloride concentration and the $\mathrm{pH}$ as a function of exposure time in the carbonation chamber for specimens S1, S2, and S4. 


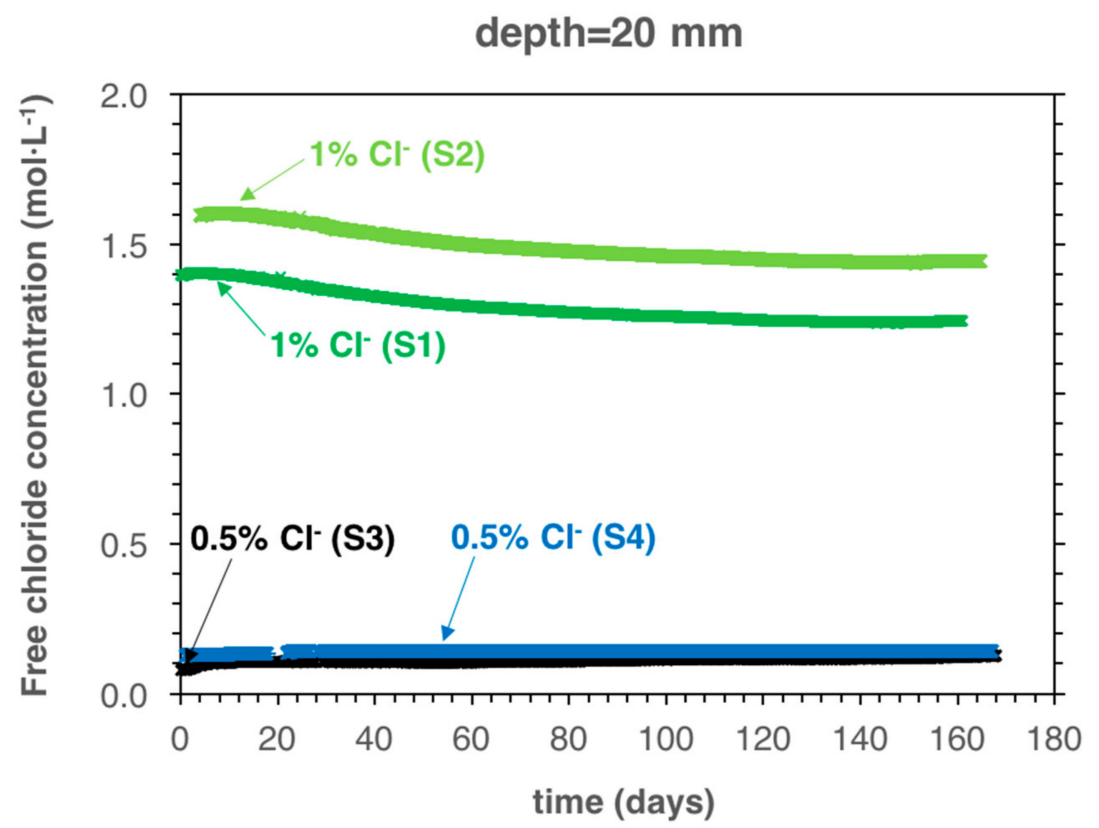

Figure 4. Measured free chloride concentration, at $20 \mathrm{~mm}$ cover depth, as a function of the exposure time in the carbonation chamber for the different samples produced (Table 1).

a)

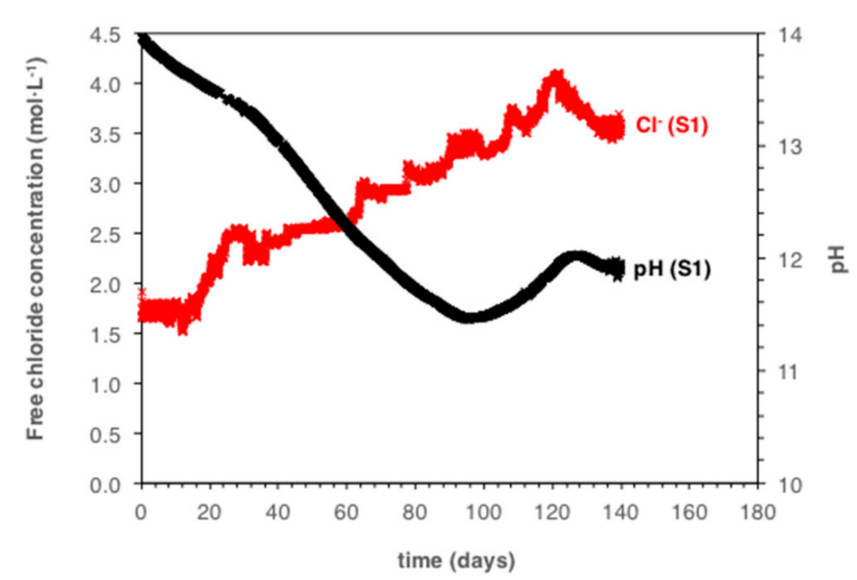

b)

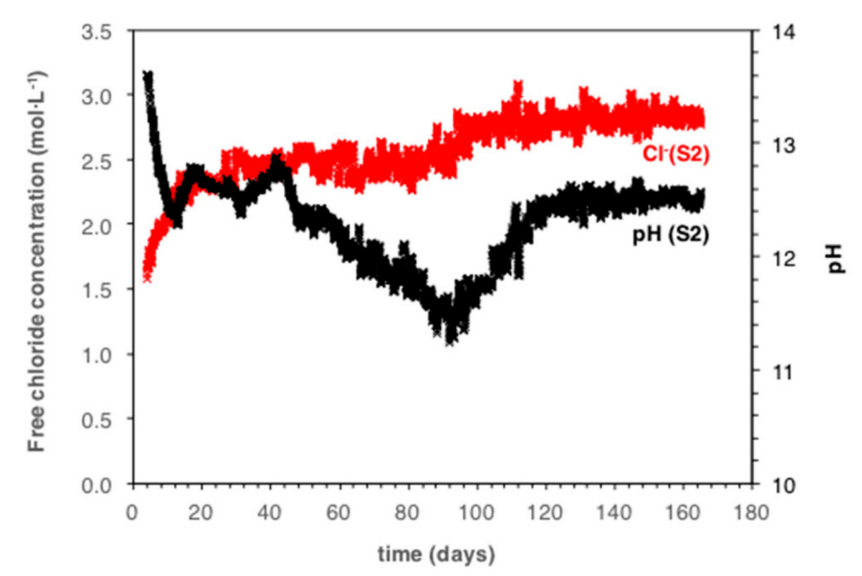

Figure 5. Cont. 
c)

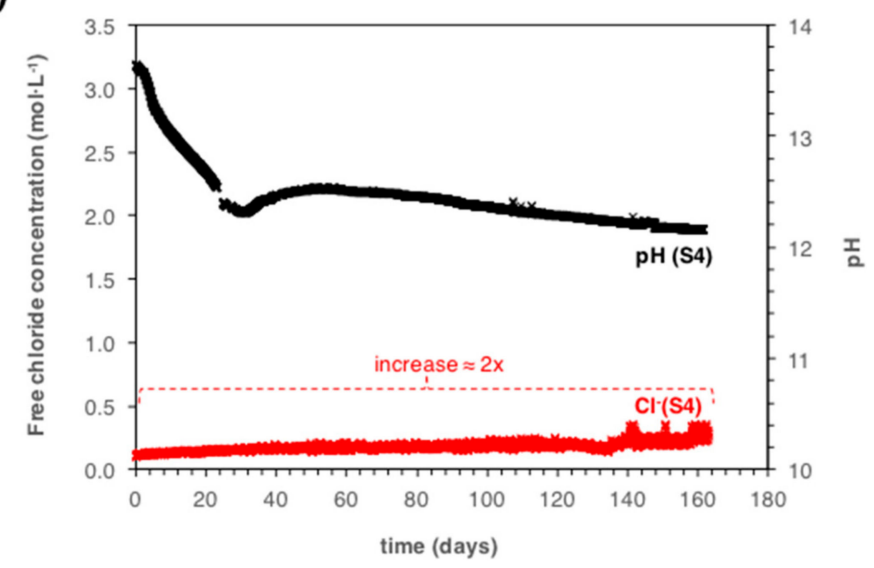

Figure 5. Measured free chloride concentration and $\mathrm{pH}$, at $5 \mathrm{~mm}$ cover depth, as a function of exposure time in the carbonation chamber for specimens S1 (a), S2 (b), and S4 (c).

From Figure 5, it can be seen that the free chloride concentration increased significantly when the $\mathrm{pH}$ of the pore solution decreased. This increase in free chlorides is most pronounced when the $\mathrm{pH}$ changes over the range $\mathrm{pH}$ 13.5-12.5. This behavior has also been reported elsewhere [39]. For sample S1, the free chloride concentration increased 1.2-fold, with respect to the initial value, when the $\mathrm{pH}$ decreased down to $\mathrm{pH} \approx 12.5$ and about 1.5-fold when the $\mathrm{pH}$ decreased down to $\mathrm{pH} \approx 11.5$. For samples S2 and S4, the free chloride concentration increased between 1.5 and 2-fold down to $\mathrm{pH} \approx 12.5$.

\section{Discussion}

\subsection{Implications on the Carbonation Process in Mortar Samples Containing Chlorides}

The simultaneous monitoring of the free chloride concentration and the $\mathrm{pH}$ in the pore solution of mortar at different depths provides new results (Figure 5). It is shown that by increasing time in the carbonation chamber, the decrease in the $\mathrm{pH}$ of the pore solution is accompanied by an increase in the free chloride concentration. No chloride ions entered into the mortar samples and this can be explained only by a release of initially bound chloride. Indeed, it is known that carbonation of the cement paste results in the release of bound chlorides due to the increase in the solubility of Friedel's salt and to the decomposition of calcium-silicate-hydrate (C-S-H) gel, which may contain adsorbed chlorides [39-44]. Applying the novel method of simultaneous monitoring of both free chloride concentration and $\mathrm{pH}$, this general mechanism that can be described in much more detail. For a $\mathrm{pH}$ drop from 13.5 down to 12.5, the free chloride concentration increased about 1.5-fold (Figure 5). The important new information compared to literature work in References [39,41,42], where full carbonation (thus $\mathrm{pH} \approx 9$ ) was reached, is that a large amount of released free chloride ions from bound chloride occurs between $\mathrm{pH} 13.5$ and 12.5 ; thus, in a range of pore solution $\mathrm{pH}$ that is usually considered "alkaline". This has implications for assessing the corrosion risk in reinforced concrete, which will be discussed in the next section.

Another interesting result found in this paper is that the samples with $1 \%$ of admixed sodium chloride showed a more pronounced but slower $\mathrm{pH}$ drop before the $\mathrm{pH}$ bounced back to $\mathrm{pH} \approx 12.5$. This decreasing and recovering effect was in Reference [34] and was explained by the dissolution kinetics of Portlandite, which are likely different in the case of admixed chloride. In fact, data from a previous study [34] indicated that carbonation of chloride-free mortar samples is faster than carbonation of chloride-containing mortar. To illustrate this, Figure 6 shows the measured $\mathrm{pH}$ as a function of exposure time in the carbonation chamber at 4 and $6 \mathrm{~mm}$ cover depth for chloride-free specimens (same experimental set-up, curing time $=$ one week) and at $4 \mathrm{~mm}$ cover depth for the samples with admixed chlorides used in this study (S1, S2, S3, and S4; curing time = 3 days). 


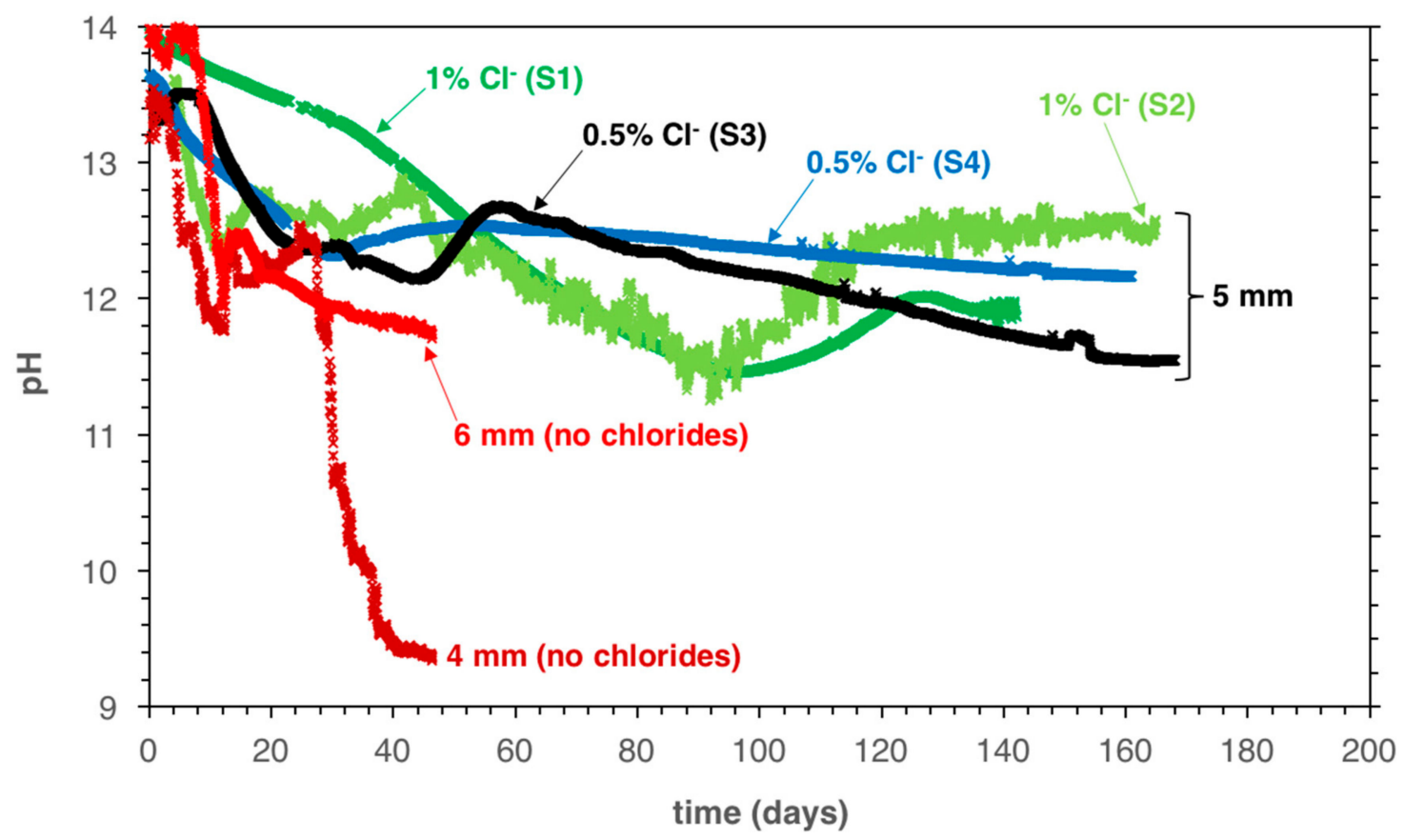

Figure 6. Comparison of measured $\mathrm{pH}$ as a function of exposure time in the carbonation chamber at 4 and $6 \mathrm{~mm}$ cover depth for chloride-free samples (curing time: 1 week) [34] and at $5 \mathrm{~mm}$ cover depth for the samples with admixed chlorides used in this study (curing time: 3 days).

From Figure 6, it can be seen that chloride-free samples showed a more pronounced decrease of the pore solution $\mathrm{pH}$ compared to samples with admixed chlorides, even if they were cured for a longer time. These results are in agreement with the data reported by Liu et al. [42], where it was shown that after one year of accelerated carbonation exposure $\left(20 \% \mathrm{CO}_{2}, 70 \% \mathrm{RH}, 20^{\circ} \mathrm{C}\right)$, the carbonation depth was reduced by approximately $20-50 \%$ for concrete samples containing admixed chlorides $(0.076 \%$ by concrete weight, or $\approx 0.5 \%$ by cement weight), compared to chloride-free samples. According to literature in References [42,45-48], it would thus be generally expected that a higher amount of admixed chlorides translates into a higher carbonation resistance. A reason for this may be that admixed chlorides accelerate cement hydration $[45,46]$ and may lead to a denser pore structure of the cement paste [42,47], which generally increases the carbonation resistance [42]. Another aspect to consider, however, is that the presence of chlorides in concrete promotes moisture retention, retarding the drying process [48], which decelerates the carbonation process under some exposure conditions. Additionally, carbonation of cement paste is a complex process [34] that comprises $\mathrm{CO}_{2}$ diffusion, changes in cement microstructure [5,49] and chemical reactions of different kinetics [5]. In order to clarify the impact of chlorides on the possible increase in carbonation resistance, the involved processes need to be studied in detail. This may include pore distribution characterization, diffusion tests, studying longer curing times, i.e., fully hydrated cement pastes, and longer drying periods, i.e., similar degree of moisture content, before carbonation. However, such investigations are beyond the scope of this paper.

\subsection{Implications for the Risk of Corrosion}

Both chloride concentration and $\mathrm{pH}$ of the concrete pore solution are important factors controlling initiation of corrosion of the reinforcing steel. Generally, the risk of corrosion increases as the ratio of chloride to hydroxyl ion concentrations $\left(\mathrm{Cl}^{-} / \mathrm{OH}^{-}\right)$rises [50-53]. A common threshold value for corrosion initiation was provided by Hausmann [53], who suggested a critical ratio $\mathrm{Cl}^{-} / \mathrm{OH}^{-}$ of 0.6 to trigger corrosion initiation. The ratio $\mathrm{Cl}^{-} / \mathrm{OH}^{-}$to promote corrosion is usually studied in simulated pore solutions where both the chloride concentration and the $\mathrm{pH}$ are defined [53-55]; however, when steel is embedded in concrete, the critical chloride/hydroxyl ion ratio to induce 
corrosion is usually considerably higher [50,52]. It thus becomes highly important to obtain data on chloride concentration and $\mathrm{pH}$ when steel is embedded in concrete.

In this work, it was found that when the pore solution $\mathrm{pH}$ decreases, the free chloride concentration increases (see Figure 5 and Section 6.1). Therefore, upon carbonation of chloridecontaining concrete, the $\mathrm{Cl}^{-} / \mathrm{OH}^{-}$ratio not only increases because of a decrease in $\mathrm{OH}^{-}$(factor 10 by one $\mathrm{pH}$ unit), but also because the $\mathrm{Cl}^{-}$concentration increases simultaneously (Figure 5). As a consequence, the risk of corrosion initiation can become significantly higher during the progress of concrete carbonation, even before full carbonation and even if initially the amount of chlorides was considered not critical. Figure 7 a shows the measured $\mathrm{Cl}^{-} / \mathrm{OH}^{-}$ratio as a function of the pore solution $\mathrm{pH}$ for mortar samples containing $1 \%$ admixed chlorides. Figure $7 \mathrm{~b}$ shows the logarithm of the measured $\mathrm{Cl}^{-} / \mathrm{OH}^{-}$ratio as a function of the pore solution $\mathrm{pH}$ for mortar samples containing $1 \%$ and $0.5 \%$ admixed chlorides. The carbonation front typically determined with the phenolphthalein (pH-indicator) spray method ( $\mathrm{pH} 9-10)[56,57]$ and the critical ratio $\mathrm{Cl}^{-} / \mathrm{OH}^{-}$of 0.6 suggested by Hausmann [53] is also indicated in the graphs by means of red and black dashed lines, respectively.

a)

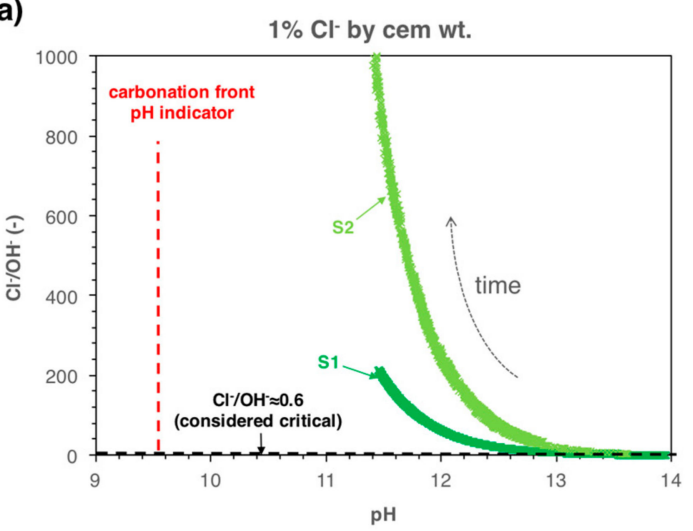

b)

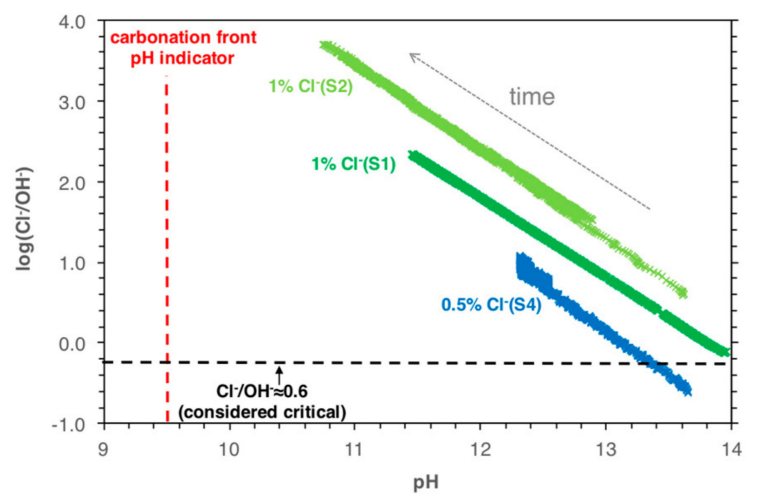

Figure 7. (a) Measured $\mathrm{Cl}^{-} / \mathrm{OH}^{-}$ratio as a function of the pore solution $\mathrm{pH}$ for mortar samples containing $1 \%$ of admixed chlorides; (b) Logarithm of measured $\mathrm{Cl}^{-} / \mathrm{OH}^{-}$ratio as a function of the pore solution $\mathrm{pH}$ for mortar samples containing 1 and $0.5 \%$ admixed chlorides.

The graphs (Figure 7) illustrate the pronounced increase in $\mathrm{Cl}^{-} / \mathrm{OH}^{-}$ratio as the pore solution $\mathrm{pH}$ decreases. For a $\mathrm{pH}$ drop from 13.5 down to 12.5 , the $\mathrm{Cl}^{-} / \mathrm{OH}^{-}$ratio increased from ca. 2.3 up to 20-100 for the specimens with $1 \%$ admixed chlorides. The curves depicted in Figure $7 \mathrm{~b}$ (logarithm of $\mathrm{Cl}^{-} / \mathrm{OH}^{-}$vs. $\mathrm{pH}$ ) are parallel with a slope of $\approx 1.1$. The fact that the slope in this graphical representation is greater than one is because the increase in $\mathrm{Cl}^{-} / \mathrm{OH}^{-}$as the $\mathrm{pH}$ decreases is not only due to a (logarithmic) decrease in the $\mathrm{OH}^{-}$concentration, but also due to the increase in the free $\mathrm{Cl}^{-}$ concentration upon carbonation.

According to the European standard EN 206-1 [37], the maximum amount of admixed chlorides in concrete permitted is $0.4 \%$ by cement weight. Various documents issues by the American Concrete Institute (ACI) stipulate allowable limits in the range of $0.15-1.0 \%$ water-soluble chloride by mass of binder [58], which supposedly corresponds to approx. 20-35\% higher values in terms of acid-soluble chlorides [59]. From Figure $7 \mathrm{~b}$, it can be seen that for similar amounts of admixed chlorides as in these international standards (here $0.5 \%$ by cement weight), highly alkaline concrete $(\mathrm{pH} \approx 13.5)$ will have a low risk of corrosion, as the $\mathrm{Cl}^{-} / \mathrm{OH}^{-}$ratio is below the critical threshold-suggested by Hausmann [53]. Once the $\mathrm{pH}$ decreases down to approx. 12.5, the $\mathrm{Cl}^{-} / \mathrm{OH}^{-}$ratio increases to approx. 10 (logarithm of $\mathrm{Cl}^{-} / \mathrm{OH}^{-}$is about 1 ), which is clearly above the critical threshold. However, a $\mathrm{pH}$ drop down to 12.5 is usually not detected in engineering practice; this is because the most established method for $\mathrm{pH}$ determination is based on the $\mathrm{pH}$-indicator spraying method, with which only $\mathrm{pH}$ drops down to 9-10 can be detected. Concrete with $\mathrm{pH} 12.5$ is generally considered "uncarbonated". 
The minimum cover depth devised in the European standards for XC classes (carbonation resistance design [37]) is to avoid carbonation at the steel within the service life, i.e., to avoid a $\mathrm{pH}$ drop down to 9 at the reinforcement level during the service life. However, as the present results suggest, if the concrete contains chlorides in the order of the allowable limits, the risk of corrosion initiation may be significant-long before carbonation is detected in the traditional manner. To lead to relevant damage, however, corrosion is also required to propagate, which depends mostly on the relative humidity [60]. Thus, in dry environments, the risk of corrosion is generally low, but in cyclic drying/wetting conditions, such as in exposure class XC4, the present results suggest that corrosion may in fact occur at allowable chloride contents and long before carbonation is detected. These results imply that allowable chloride limits set in international standards may need reconsideration for some exposure situations.

Finally, the possibility of simultaneous monitoring of both free chloride concentration and $\mathrm{pH}$ in mortar or concrete is of course not limited to this example but opens new research opportunities as well as field applications. Deploying these sensors in structures to monitor in-situ the $\mathrm{Cl}^{-} / \mathrm{OH}^{-}$ ratio in the concrete cover during the life of a structure would significantly refine the assessment of the corrosion risk of the structure. On the one hand, the sensors may act as an early warning system, and on the other hand, measurements at different depths may allow for more reliability than the present forecast at the time at which a repair intervention will be needed. Thus, these measurements may in the future be used in engineering practices to assist in the decision-taking and maintenance planning of reinforced concrete infrastructures.

\subsection{Suggestions for Further Research}

If chloride salts other than $\mathrm{NaCl}$ are used, the conclusions set in this work may change. For example, in the presence of $\mathrm{CaCl}_{2}$, the $\mathrm{pH}$ was found to decrease when increasing the $\mathrm{CaCl}_{2}$ content, and the amount of bound chlorides seemed to increase when decreasing the pore solution $\mathrm{pH}[61,62]$. We propose that further research should also focus on the impact of $\mathrm{pH}$ changes on the $\mathrm{Cl}^{-} / \mathrm{OH}^{-}$ratio in the alkaline range (approx. 11-13.5). This may include $\mathrm{pH}$ changes occurring in the concrete during carbonation, and also $\mathrm{pH}$ changes due to leaching or pozzolanic reactions in blended cements. We believe that the approach presented in this paper would be a useful novel tool to shed light on the occurring phenomena, both the kinetics of $\mathrm{pH}$ changes (carbonation, leaching, pozzolanic reactions) and the associated release of bound chlorides.

The strong influence of $\mathrm{pH}$ on the $\mathrm{Cl}^{-} / \mathrm{OH}^{-}$ratio could be one of the reasons for the high scatter in the reported critical chloride content found in the literature [52]. While it is impossible to revisit literature data under this aspect, it is suggested that future studies aiming at determining the critical chloride content should pay more attention at $\mathrm{pH}$ changes in the alkaline range (that is, above traditional carbonation testing).

Currently, the presented measurement technology is applied in different engineering structures in the form of pilot projects to monitor chloride concentration and $\mathrm{pH}$ under actual exposure conditions.

\section{Conclusions}

In this work, we used a novel method to simultaneously monitor the free chloride concentration and the $\mathrm{pH}$ of the pore solution of mortar specimens when subjected to accelerated carbonation. The approach takes advantage of a recently developed electrode system, composed of several $\mathrm{Ag} / \mathrm{AgCl}$ ion-selective electrodes and iridium/iridium oxide $\left(\mathrm{IrO}_{\mathrm{x}}\right)$ electrodes in combination with a calculation procedure explained elsewhere [27]. Our results on the development over time of both free chloride concentration and $\mathrm{pH}$ in the concrete pore solution, presented in this paper, reveal a relationship between the two parameters and have the following main implications:

The free chloride concentration can increase up to 1.5-fold for a $\mathrm{pH}$ drop of about $1 \mathrm{pH}$ unit (from ca. $\mathrm{pH} 13.5$ down to ca. $\mathrm{pH}$ 12.5). This release of bound chlorides in the still highly alkaline range of the carbonation process, together with the decrease in $\mathrm{OH}^{-}$concentrations, can lead to 
critical $\mathrm{Cl}^{-} / \mathrm{OH}^{-}$ratios in the pore solution and thus present a corrosion risk in reinforced concrete, long before carbonation or critical total chloride contents are detected in current engineering practice.

Depending on exposure conditions and cement types used, the allowable chloride limits set in standards may need to be reconsidered. Carbonation, leaching, and pozzolanic reactions may reduce the $\mathrm{pH}$ to an extent where the amount of bound chlorides may be currently overestimated.

The presence of chlorides may increase the carbonation resistance of hardened cement paste; however, the effect of other factors such as increased moisture content, different microstructure, or the higher degree of hydration in the presence of chlorides needs to be studied in detail.

Author Contributions: Y.S. designed, carried out and interpreted the major part of the experiments. Y.S. also wrote the major part of this manuscript. U.A. was specially involved in the discussion of the experimental part. U.A. also provided many highly-valuable and complete contributions to the manuscript. F.M. and B.E. contributed with many useful comments that increased the quality of the paper.

Acknowledgments: The authors would like to acknowledge Karima Chliah for her support in the experimental work.

Conflicts of Interest: The authors declare no conflict of interest.

\section{References}

1. Flatt, R.J.; Roussel, N.; Cheeseman, C.R. Concrete: An eco material that needs to be improved. J. Eur. Ceram. Soc. 2012, 32, 2787-2798. [CrossRef]

2. Gehlen, C.; Matthews, S.; Osterminski, K.; Straub, D.; Kessler, S.; Mayer, T.F.; Greve-Dierfeld, V.S.; Zintel, M. Condition Control and Assessment of Reinforced Concrete Structures Exposed to Corrosive Environments; Technical Report for International Federation of Structural Concrete (FIB): Lausanne, Switzerland, May 2011.

3. Jones, A.E.K.; Marsh, B.; Clark, L.; Seymour, D.; Basheer, P.; Long, A. Development of An Holistic Approach to Ensure the Durability of New Concrete Construction; British Cement Association: Camberley, UK, 1997.

4. Raupach, M.; Elsener, B.; Polder, R.; Miet, J. Corrosion of Reinforcement in Concrete; CRC Press: Boca Raton, FL, USA, 2007.

5. Bertolini, L.; Elsener, B.; Pedeferri, P.; Redaelli, E.; Polder, R.P. Corrosion of Steel in Concrete: Prevention, Diagnosis, Repair, 2nd ed.; Join Wiley \& Sons: Weinheim, Germany, 2013.

6. Koch, G.H.; Brongers, M.P.H.; Thomson, N.G.; Virmani, Y.P.; Payer, J.H. Corrosion Cost and Preventive Strategies in the United States; Technical report for Federal Highway Administration, US Department of Transportation: Washington, DC, USA, March 2002.

7. Polder, R.B.; Peelen, W.H.A.; Courage, W.M.G. Non-traditional assessment and maintenance methods for aging concrete structures-Technical and non-technical issues. Mater. Corros. 2012, 63, 1147-1153. [CrossRef]

8. Angst, U.M. Challenges and opportunities in corrosion of steel in concrete. Mater. Struct. 2018, 51, 1.

9. Koch, G. Cost of corrosion. In Trends in Oil and Gas Corrosion Research and Technologies, 1st ed.; El-Sherik, A.M., Ed.; Woodhead Publishing: Cambridge, UK, 2017; pp. 3-30.

10. Schiegg, Y.; Steiner, L. Cost effectiveness and application of online monitoring in reinforced concrete structures. Mater. Corros. 2010, 61, 490-493. [CrossRef]

11. Figueira, R. Electrochemical sensors for monitoring the corrosion conditions of reinforced concrete structures: A review. Appl. Sci. 2017, 7, 1157. [CrossRef]

12. Raupach, M.; Schießl, P. Macrocell sensor systems for monitoring of the corrosion risk of the reinforcement in concrete structures. NDT E Int. 2001, 34, 435-442. [CrossRef]

13. Raupach, M.; Schiessl, P. Monitoring system for the penetration of chlorides, carbonation and the corrosion risk for the reinforcement. Constr. Build. Mater. 1997, 11, 207-214.

14. Xu, C.; Li, Z.; Jin, W. A new corrosion sensor to determine the start and development of embedded rebar corrosion process at coastal concrete. Sensors 2013, 13, 13258-13275. [CrossRef] [PubMed]

15. Schiessl, P.; Raupach, M. Monitoring system for the corrosion risk of steel in concrete structures. Concr. Int. 1992, 14, 52-55.

16. Leung, C.K.Y.; Wan, K.T.; Chen, L. A novel optical fiber sensor for steel corrosion in concrete structures. Sensors 2008, 8, 1960-1976. [CrossRef] [PubMed] 
17. Schiessl, P.; Breit, W. Monitoring of the depth-dependent moisture content of concrete using multi-ring electrodes. In Proceedings of the Concrete Under Severe Conditions: Environment and Loading, Sapporo, Japan, 2-4 August 1995.

18. Angst, U.; Elsener, B.; Larsen, C.K.; Vennesland, Ø. Potentiometric determination of the chloride ion activity in cement based materials. J. Appl. Electrochem. 2010, 40, 561-573. [CrossRef]

19. Montemor, M.F.; Alves, J.H.; Simões, A.M.; Fernandes, J.C.S.; Lourenço, Z.; Costa, A.J.S.; Appleton, A.J.; Ferreira, M.G.S. Multiprobe chloride sensor for in situ monitoring of reinforced concrete structures. Cem. Concr. Compos. 2006, 28, 233-236. [CrossRef]

20. Elsener, B.; Zimmermann, L.; Böhni, H. Non destructive determination of the free chloride content in cement based materials. Mater. Corros. 2003, 54, 440-446. [CrossRef]

21. Du, R.G.; Hu, R.G.; Huang, R.S.; Lin, C.J. In situ measurement of $\mathrm{Cl}^{-}$concentrations and $\mathrm{pH}$ at the reinforcing steel/Concrete interface by combination sensors. Anal. Chem. 2006, 78, 3179-3185. [CrossRef] [PubMed]

22. Dong, S.G.; Lin, C.J.; Hu, R.G.; Li, L.Q.; Du, R.G. Effective monitoring of corrosion in reinforcing steel in concrete constructions by a multifunctional sensor. Electrochim. Acta 2011, 56, 1881-1888. [CrossRef]

23. Gandía-Romero, J.M.; Campos, I.; Valcuende, M.; García-Breijo, E.; Marcos, M.D.; Payá, J.; Soto, J. Potentiometric thick-film sensors for measuring the $\mathrm{pH}$ of concrete. Cem. Concr. Compos. 2016, 68, 66-76. [CrossRef]

24. Myrdal, R. The Electrochemistry and Characteristics of Embeddable Reference Electrodes for Concrete, 1st ed.; Woodhead Publishing Ltd.: Cambridge, UK, 2007.

25. Bard, A.J.; Faulkner, L.R. Electrochemical Methods: Fundamentals and Applications, 2nd ed.; Willey: New York, NY, USA, 2001.

26. Angst, U.; Vennesland, Ø.; Myrdal, R. Diffusion potentials as source of error in electrochemical measurements in concrete. Mater. Struct. 2009, 42, 365-375. [CrossRef]

27. Seguí Femenias, Y. Electrochemical Durability Monitoring in Reinforced Concrete. Ph.D. Thesis, ETH Zürich, Zürich, Switzerland, October 2017.

28. Seguí Femenias, Y.; Angst, U.; Caruso, F.; Elsener, B. Ag/ AgCl ion-selective electrodes in neutral and alkaline environments containing interfering ions. Mater. Struct. 2016, 49, 2637-2651. [CrossRef]

29. Seguí Femenias, Y.; Angst, U.; Elsener, B. Monitoring chloride concentrations in concrete by means of $\mathrm{Ag} / \mathrm{AgCl}$ ion-selective electrodes. In Proceedings of 4th International Conference on Concrete Repair, Leipzig, Germany, 5-7 October 2015.

30. Koryta, J. Theory and applications of ion-selective electrodes. Anal. Chim. Acta 1972, 61, 329-411. [CrossRef]

31. Shreir, L. Corrosion control. In Corrosion, 3rd ed.; Shreir, L., Jarman, R.A., Burstein, G.T., Eds.; ButterworthHeinemann Ltd.: Oxford, UK, 1994; Volume 2.

32. Atkins, C.P.; Carter, M.A.; Scantlebury, J.D. Sources of error in using silver/silver chloride electrodes to monitor chloride activity in concrete. Cem. Concr. Res. 2001, 31, 1207-1211. [CrossRef]

33. Seguí Femenias, Y.; Angst, U.; Elsener, B. Monitoring $\mathrm{pH}$ in corrosion engineering by means of thermally-produced iridium oxide electrodes. Mater. Corros. 2018, 69, 76-88. [CrossRef]

34. Seguí Femenias, Y.; Angst, U.; Elsener, B. PH-monitoring in mortar with thermally-oxidized iridium electrodes. RILEM Tech. Lett. 2017, 2, 59-66. [CrossRef]

35. Myrdal, R. Potential Gradients in Concrete Caused by Charge Separations in a Complex Electrolyte; NACE International: New Orleans, LA, USA, 1997.

36. Myrdal, R. Phenomena that Disturb the Measurement of Potentials in Voncrete; NACE International: Denver, CO, USA, 1996.

37. Schiegg, Y.; Büchler, M.; Brem, M. Potential mapping technique for the detection of corrosion in reinforced concrete structures: Investigation of parameters influencing the measurement and determination of the reliability of the method. Mater. Corros. 2009, 60,79-86. [CrossRef]

38. Chatterji, S. Transportation of ions through cement based materials. Part 3. Experimental evidence for the basic equations and some important deductions. Cem. Concr. Res. 1994, 24, 1229-1236. [CrossRef]

39. Reddy, B.; Glass, G.K.; Lim, P.J.; Buenfeld, N.R. On the corrosion risk presented by chloride bound in concrete. Cem. Concr. Compos. 2002, 24, 1-5. [CrossRef]

40. Justnes, H. A review of chloride binding in cementitious systems. Nordic Concr. Res. 1998, 21, 1-6.

41. Geng, J.; Easterbrook, D.; Liu, Q.-F.; Li, L.Y. Effect of carbonation on release of bound chlorides in chloride-contaminated concrete. Mag. Concr. Res 2016, 68, 353-363. [CrossRef] 
42. Liu, W.; Cui, H.; Dong, Z.; Xing, F.; Zhang, H.; Lo, T.Y. Carbonation of concrete made with dredged marine sand and its effect on chloride binding. Constr. Build. Mater. 2016, 120,1-9. [CrossRef]

43. Tuutti, K. Corrosion of Steel in Concrete. Ph.D. Thesis, Swedish Cement and Concrete Research Institute, Stockholm, Sweden, January 1982.

44. Suryavanshi, A.K.; Swamy, R.N. Stability of friedel's salt in carbonated concrete structural elements. Cem. Concr. Res. 1996, 26, 729-741. [CrossRef]

45. Vehmas, T.; Kronlöf, A.; Cwirzen, A. Calcium chloride acceleration in ordinary portland cement. Mag. Concr. Res. 2018, 70, 856-863. [CrossRef]

46. Cheung, J.; Jeknavorian, A.; Roberts, L.; Silva, D. Impact of admixtures on the hydration kinetics of portland cement. Cem. Concr. Res. 2011, 41, 1289-1309. [CrossRef]

47. Suryavanshi, A.K.; Scantlebury, J.D.; Lyon, S.B. Pore size distribution of opc \& srpc mortars in presence of chlorides. Cem. Concr. Res. 1995, 25, 980-988.

48. Glass, G.K.; Page, C.L.; Short, N.R. Factors affecting the corrosion rate of steel in carbonated mortars. Corros. Sci. 1991, 32, 1283-1294. [CrossRef]

49. Hidalgo, A.; Domingo, C.; Garcia, C.; Petit, S.; Andrade, C.; Alonso, C. Microstructural changes induced in Portland cement-based materials due to natural and supercritical carbonation. J. Mater. Sci. 2008, 43, 3101-3111. [CrossRef]

50. Lambert, P.; Page, C.L.; Vassie, P.R.W. Investigations of reinforcement corrosion. 2. Electrochemical monitoring of steel in chloride-contaminated concrete. Mater. Struct. 1991, 24, 351-358. [CrossRef]

51. Glass, G.K.; Buenfeld, N.R. The presentation of the chloride threshold level for corrosion of steel in concrete. Corros. Sci. 1997, 39, 1001-1013. [CrossRef]

52. Angst, U.; Elsener, B.; Larsen, C.K.; Vennesland, Ø. Critical chloride content in reinforced concrete-A review. Cem. Concr. Res. 2009, 39, 1122-1138. [CrossRef]

53. Hausmann, D.A. Corrosion of steel in concrete-How does it occur? J. Mater. Prot. 1967, 6, $19-23$.

54. Moreno, M.; Morris, W.; Alvarez, M.G.; Duffó, G.S. Corrosion of reinforcing steel in simulated concrete pore solutions. Corros. Sci. 2004, 46, 2681-2699. [CrossRef]

55. Yu, H.; Chiang, K.T.K.; Yang, L. Threshold chloride level and characteristics of reinforcement corrosion initiation in simulated concrete pore solutions. Constr. Build. Mater. 2012, 26, 723-729. [CrossRef]

56. Plusquellec, G.; Geiker, M.R.; Lindgård, J.; Duchesne, J.; Fournier, B.; Weerdt, K.D. Determination of the pH and the free alkali metal content in the pore solution of concrete: Review and experimental comparison. Cem. Concr. Res. 2017, 96, 13-26. [CrossRef]

57. Yu, M.Y.; Lee, J.Y.; Chung, C.W. The application of various indicators for the estimation of carbonation and pH of cement based materials. J. Test. Eval. 2010, 38, 534-540.

58. Trejo, D.; Isgor, O.B.; Weiss, W.J. The allowable admixed chloride conundrum: A review of how ACI Committee documents define maximum chlorides in fresh concrete. Concr. Int. 2016, 38, 35-42.

59. Bremner, T.; Hover, K.; Poston, R.; Broomfield, J.; Joseph, T.; Price, R.; Clear, K.; Khan, M.; Reddy, D.V.; Clifton, J.; et al. Protection of Metals in Concrete against Corrosion; Technical report for ACI Committee 222: Farmington Hills, MI, USA, 2001.

60. Stefanoni, M.; Angst, U.; Elsener, B. Corrosion rate of carbon steel in carbonated concrete-A critical review. Cem. Concr. Res. 2018, 103, 35-48. [CrossRef]

61. De Weerdt, K.; Colombo, A.; Coppola, L.; Justnes, H.; Geiker, M.R. Impact of the associated cation on chloride binding of Portland cement paste. Cem. Concr. Res. 2015, 68, 196-202. [CrossRef]

62. Shi, Z.; Geiker, M.R.; De Weerdt, K.; Østnor, T.A.; Lothenbach, B.; Winnefeld, F.; Skibsted, J. Role of calcium on chloride binding in hydrated Portland cement-metakaolin-limestone blends. Cem. Concr. Res. 2017, 95, 205-216. [CrossRef]

(C) 2018 by the authors. Licensee MDPI, Basel, Switzerland. This article is an open access article distributed under the terms and conditions of the Creative Commons Attribution (CC BY) license (http:/ / creativecommons.org/licenses/by/4.0/). 